\title{
Penerapan Asuhan Keperawatan Jiwa Pada An. A Dengan Gangguan Konsep Diri : Harga Diri Rendah Di Lingk. XVI Lorong Jaya
}

\section{Erma Fitri Samosir}

ermasamosir1122@gmail.com

\section{BAB 1 \\ PENDAHULUAN}

\subsection{Latar Belakang}

Skizofrenia merupakan gangguan mental yang ditandai dengan gangguan proses berpikir dan respons emosional yang lemah. Situasi ini umumnya merupakan gangguan berpikir disertai dengan disfungsi sosial dan bicara kacau balau. Gejala skizofrenia salah satunya negatif yaitu harga diri yang rendah (Pardede, Keliat, dan Yulia, 2020). Data yang diperoleh dari Medical Record Rumah Sakit Jiwa Prof.Dr.M.Ildrem Provsu Medan tahun 2017, pasien yang menderita skizofrenia sebanyak 13,846 (85.3\%) (Pardede dan Hasibuan, 2019). Harga diri rendah muncul akibat dari penilaian internal individu maupun penilaian eksternal yang negative (Fatah,2018).

Harga diri yang tinggi digambarkan dari sifat individu yang memiliki perasaan penerimaan diri tanpa syarat, meski salah, kalah dan gagal, sebagai yang berharga dan sifat penting untuk dirinya sendiri. Individu yang memiliki perasaan tidak berharga, tidak berarti, dan harga diri rendah yang berkepanjangan karena evaluasi negatif terhadap diri mereka sendiri dan diri mereka sendiri kemampuan merupakan gambaran seseorang yang memiliki harga diri yang rendah (Pardede dan Laia, 2020).

Penatalaksaan harga diri rendah yaitu dengan komunikasi terapeutik, komunikasi terapeutik ini merupakan suatu komunikasi yang direncanakan secara sadar, bertujuan dan kegiatannya dipusatkan untuk kesembuhan klien. Komunikasi terapeutik memperhatikan klien secara holistik meliputi aspek 
keselamatan, menggali penyebab, tanda-tanda dan mencari jalan terbaik atas permasalahan klien. Selain itu hubungan saling percaya antara perawat dan klien merupakan dasar utama dalam melakukan asuhan keperawatan pada klien gangguan jiwa (Purwasih dan Susilowati, 2016).

Klien dengan harga diri mulai terbentuk setelah anak lahir, ketika anak berhadapan dengan dunia luar dan berinteraksi dengan orang-orang di lingkungan sekitarnya. Interaksi secara minimal memerlukan pengakuan, penerimaan peran yang saling tergantung pada orang yang bicara dan orang yang diajak bicara. Interaksi menimbulkan pengertian tentang kesadaran diri, identitas, dan pemahaman tentang diri. Hal ini akan membentuk penilaian individu terhadap dirinya sebagai orang yang berarti dan berharga, sehingga individu mempunyai perasaan harga diri (Hidayati, 2016).

Pasien harga diri rendah biasanya memiliki lebih dari satu masalah keperawatan. Sejumlah masalah pasien akan saling berhubungan dan dapat digambarkan sebagai pohon masalah (Elvidiana dan Fitriani, 2019). Upaya untuk menangani klien harga diri rendah adalah dengan memberikan tindakan keperawatan generalis yang dilakukan oleh . Tindakan keperawatan pada klien harga diri rendah bisa secara individu, terapi keluarga dan penanganan di komunitas baik generalis ataupun spesialis (Wakhid dan Hamid, 2013).

Survei awal pada pembuatan askep pada skizofrenia ini dilakukan di Lingk. XVI Lorong Jaya, Mabar Kec. Medan Deli yang ditemukan pasien gangguan konsep diri : harga diri rendah atas nama inisial An.A yang pernah di rawat di RSJ. Penyebabnya An.A dijadikan subjek dikarenakan An.A belum sepenuhnya bisa mengatasi harga diri rendahnya. Maka tujuan asuhan keperawatan yang akan di lakukan ialah untuk mengajarkan standar pelaksanaan gangguan konsep diri : harga diri rendah atau cara mengindentifikasi kemampuan dan aspek positif yang dimiliki pasien.

\subsection{Rumusan Masalah}


Berdasarkan latar belakang masalah tersebut maka dapat dirumuskan masalah saebagai berikut :"Bagaimana penerapan Asuhan Keperawatan Pada An.A dengan masalah gangguan arga diri rendah kronis dan ketidakberdayaan di Lingk. XVI Lorong Jaya, Mabar Kec. Medan Deli”

\subsection{Tujuan Penulisan}

\section{Tujuan Umum}

Memberikan asuhan keperawatan jiwa Pada An.A dengan masalah gangguan arga diri rendah kronis dan ketidakberdayaan di Lingk. XVI Lorong Jaya, Mabar Kec. Medan Deli

\section{Tujuan Khusus}

1. Mahasiswa mampu memahami pengertian, tanda dan gejala, etiologi, penatalaksanaan medis dan keperawatan gangguan konsep diri : harga diri rendah.

2. Mahasiswa mampu melakukan pengkajian pada An. A dengan gangguan konsep diri : harga diri rendah.

3. Mahasiswa mampu melakukan menegakkan diagnosa pada An. A dengan gangguan konsep diri : harga diri rendah.

4. Mahasiswa mampu melakukan menetapkan perencanaan pada An. A dengan gangguan konsep diri : harga diri rendah.

5. Mahasiswa mampu melakukan implementasi pada An.A dengan gangguan konsep diri : harga diri rendah.

6. Mahasiswa mampu melakukan evaluasi pada An. A dengan gangguan konsep diri : harga diri rendah.

7. Mahasiswa mampu mendokumentasikan asuhan keperawatan yang diberikan pada An. A dengan gangguan konsep diri : harga diri rendah. 


\subsection{Manfaat}

\section{Pasien}

Diharapkan tindakan yang telah di ajakarkan dapat di terapkan secara mandiri untuk mengindetifikasi kemampuan yang dimiliki pasien.

\section{Keluarga}

Diharapkan keluarga dapat memberikan dukungan moral, emosional dan spiritual serta membantu dalam menerapkan asuhan keperawatan jiwa kepada pasien dengan masalah ganggan konsep diri: harga diri rendah. 


\section{BAB 2 \\ TINJAUAN TEORITIS}

\subsection{Konsep Dasar Harga Diri Rendah Kronis}

\subsubsection{Pengertian Harga Diri Rendah Kronis}

Harga diri rendah adalah disfungsi psikologis yang meluas dan terlepas dari spesifiknya. Masalahnya, hampir semua pasien menyatakan bahwa mereka ingin memiliki harga diri yang lebih baik. Jika kita hanya mengurangi harga diri rendah, banyak masalah psikologis akan berkurang atau hilang secara substansial sepenuhnya. Harga diri merupakan komponen psikologis yang penting bagi kesehatan. Banyak penelitian sebelumnya menunjukkan bahwa harga diri yang rendah sering kali menyertai gangguan kejiwaan (Sitanggang, et al, 2021).

Harga diri yang tinggi dikaitkan dengan kecemasan yang rendah, efektif dalam kelompok dan penerimaan orang lain terhadap dirinya, sedangkan masalah kesehatan dapat menyebabkan harga diri, sehingga harga diri dikaitkan dengan hubungan interperonal yang buruk dan beresiko terjadinya depresisehingga perasaan negatif mendasari hilangnya kepercayaan diri dan harga diri individu dan menggambarkan gangguan harga diri (Wandono, 2017).

Harga diri rendah dapat digambarkan sebagai perasaan negatif terhadap diri sendiri termasuk hilangnya percaya diri dan harga diri. Harga diri rendah dapat terjadi secara situasional (trauma) atau kronis (negatif self evaluasi yang telah berlangsung lama). Dan dapat di ekspresikan secara langsung atau tidak langsung (nyata atau tidak nyata) (Yusuf, 2014).

\subsubsection{Rentang Respon Harga Diri Rendah Kronis}

Menurut Dermawan, (2013) tentang respon konsep diri dapat dilihat pada gambar berikut ini: 


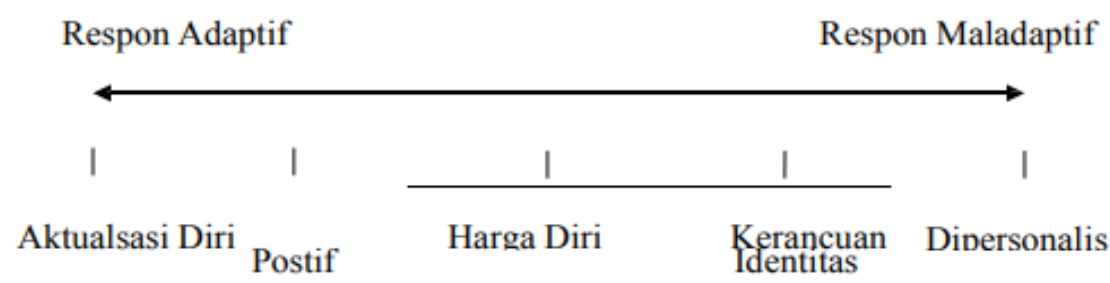

Keterangan :

1. Aktualisasi diri : Pernyataan tentang konsep diri yang positif dengan pengalaman latar belakang sukses.

2. Konsep diri positif : Apabila individu mempunyai pengalaman yang positif dalam perwujudan dirinya.

3. Harga diri rendah : Perasaan negatif terhadapa diri sendiri, termasuk kehilangan rasa percaya diri, tidak berharga, tidak berdaya, pesimis.

4. Kerancuan identitas : Kegagalan individu untuk mengintegrasikan berbagai identifikasi masa kanak-kanak kedalam kepribadian psikososial dewasa yang harmonis.

5. Dipersonalisasi : Perasaan tidak realitik dalm kegiatan dari diri sendiri, kesulitan membedakan diri sendiri, merasa tidak nyata dan asing baginya.

\subsubsection{Faktor Predisposisi dan Faktor Presipitasi Harga Diri Rendah}

Menurut Rahayu, Mustikasari \& Daulima, (2019) fakor predisposisi dan faktor presipitasi harga diri rendah ialah :

1. Aspek Biologis Sebagian besar pasien memiliki riwayat gangguan jiwa sebelumnya (75\%), Sebagian kecil memiliki riwayat genetik (25\%). Faktor genetik berperan dalam mencetuskan terjadinya gangguan jiwa pada diri seseorang. Sadock dan Sadock (2007) menyampaikan bahwa genetik memiliki peran pada pasien skizofrenia. Seseorang beresiko $10 \%$ jika salah satu orang tua menderita gangguan dan jika 
kedua orang tua memiliki riwayat gangguan maka resiko akan lebih besar, yaitu menjadi $40 \%$.

2. Aspek Psikologis Pasien HDR kronis yang diberikan terapi kognitif memiliki riwayat psikologis kurang percaya diri (90\%). Menurut Stuart (2016) bahwa faktor psikologis meliputi konsep diri, intelektualitas, kepribadian, moralitas, pengalaman masa lalu, koping dan keterampilan komunikasi secara verbal mempengaruhi perilaku seseorang dalam hubungannya dengan orang lain.

3. Aspek Sosial Budaya Pasien yang diberikan terapi kognitif dan psikoedukasi keluarga memiliki masalah sosial budaya yang sangat berpengaruh yaitu tidak memiliki teman (85\%), konflik keluarga (80\%) dan status ekonomi rendah (70\%). Townsend (2009) menyatakan bahwa status sosioekonomi yang rendah lebih banyak mengalami gangguan jiwa dibandingkan tingkat sosio ekonomi tinggi.

\subsubsection{Manifestasi Klinis Harga Diri Rendah}

Tanda dan gejala harga diri rendah menurut Muhith, (2015).

1. Perasaan malu terhadap diri sendiri akibat adanya penyakit atau akibat tindakan terhadap penyakit.

2. Rasa bersalah terhadap diri sendiri. Individu merasa tidak mampu dan tidak berguna dan memandang dirinya lemah.

3. Gangguan hubungan sosial, seperti menarik diri dari masyarakat. Individu merasa tidak berguna sehingga klien merasa lebih suka meyendiri dan enggan untuk berinteraksi dengan lingkungan masyarakat.

4. Merendahkan martabat. Individu merasa dirinya lemah merasa bodoh, merasa tidak mampu dalam melakukan segala hal, dan individu merasa tidak tahu apa-apa, mengabaikan bahkan menolak kemampuan yang dimiliki sehingga produktivitas individu menurun. 
5. Percaya diri kurang. Individu merasa ragu-ragu dalam mengambil keputusan, individu tidak memiliki rasa percaya pada dirinya dan individu selalu memandnag dirinya negatif.

6. Mencederai diri sendiri dan orang lain. Akibat harga diri rendah individu memandang hidupnya pesimis, tidak berguna sehingga terdorong untuk merusak atau mengakhiri hidupnya. Bahkan klien dengan harga diri rendah timbul perasaan benci dan dapat menimbulkan perilaku kekerasan terhadap lingkungan sekitar

\subsubsection{Proses Terjadinya Harga Diri Rendah}

Harga diri rendah kronis terjadi merupakan proses kelanjutan dari harga diri rendah situasional yang tidak terselesaikan. Atau dapat juga terjadi karena individu tidak pernah mendapat feed back dari lingkungan tentang prilaku klien sebelumnya bahkan kecendrungan lingkungan yang selalu memberi respon negatif mendorong individu menjadi harga diri rendah (Muhith, 2015).

Harga diri rendah kronis terjadi disebabkan banyak faktor. Awalnya individu berada pada suatu situasi yang penuh dengan stressor (krisis), individu berusaha menyelesaikan krisis tetapi tidak mampu atau merasa gagal menjalankan fungsi dan peran. Penilaian individu terhadap diri sendiri karena kegagalan menjalankan fungsi dan peran adalah kondisi harga diri rendah situasional, jika lingkungan tidak memberi dukungan positif atau justru menyalahkan individu dan terjadi secara terus menerus akan mengakibatkan individu mengalami harga diri rendah kronis (Masturah, 2017). 


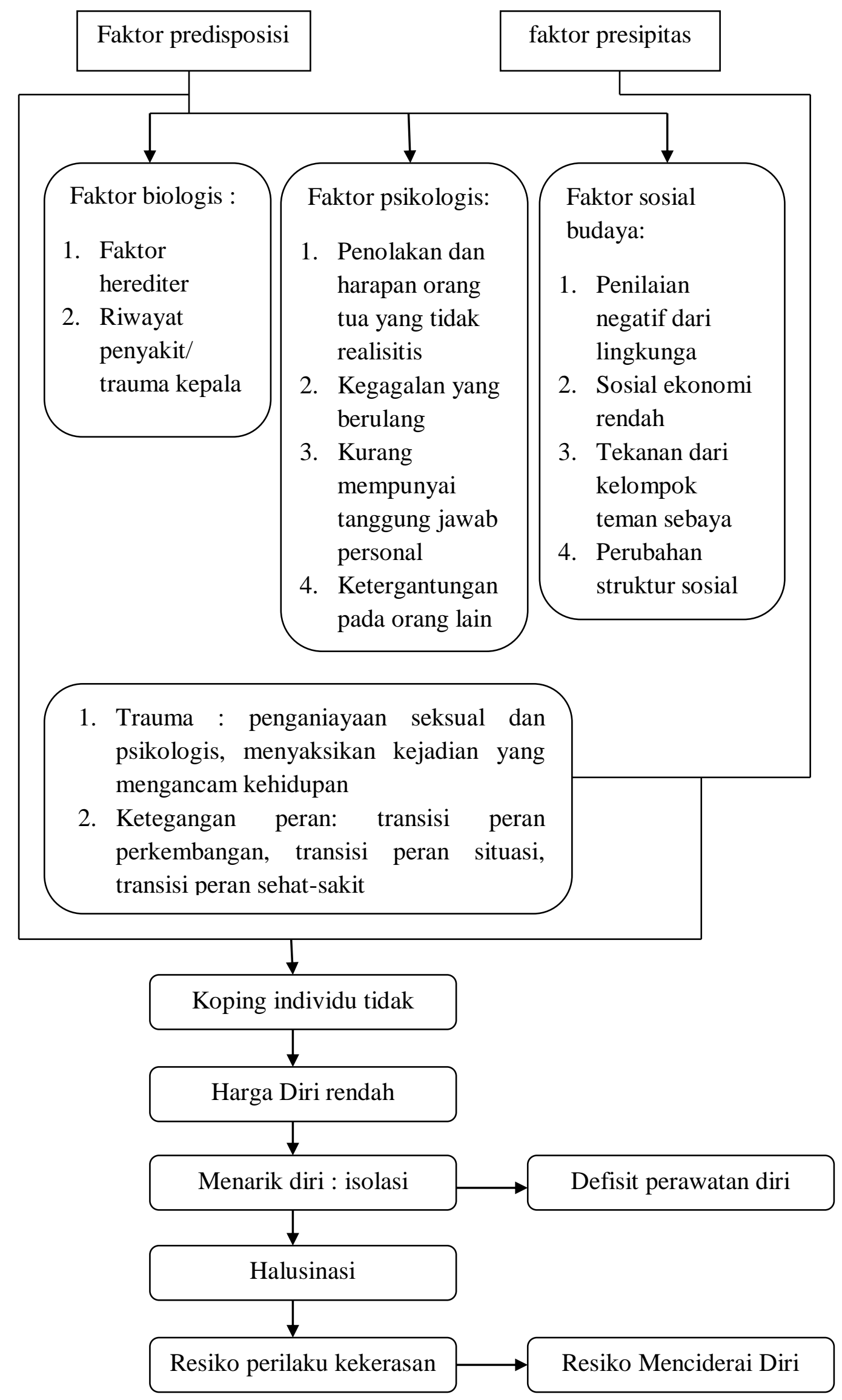




\subsubsection{Tanda dan Gejala Harga Diri Kronis}

Tanda dan gejala harga diri rendah dapat dinilai dari ungkapan pasien yang menunjukkan penilaian tentang dirinya dan didukung dengan data hasil wawancara dan observasi (Kemenkes RI, 2019).

a. Data subjektif Pasien mengungkapkan tentang:

1. Hal negatif diri sendiri atau orang lain

2. Perasaan tidak mampu

3. Pandangan hidup yang pesimis

4. Penolakan terhadap kemampuan diri

b. Data objektif

1. Penurunan produktifitas

2. Tidak berani menatap lawan bicara

3. Lebih banyak menundukkan kepala saat berinteraksi

4. Bicara lambat dengan nada suara rendah

Manifestasi yang bisa muncul pada klien gangguan jiwa dengan harga diri rendah adalah:

1. Mengkritik diri sendiri

2. Perasaan tidak mampu

3. Pandangan hidup yang pesimistis

4. Tidak menerima pujian

5. Penurunan produktivitas

6. Penolakan terhadap kemampuan diri

7. Kurang memperhatikan perawatan diri

8. Berpakaian tidak rapi

9. selera makan kurang

10. Tidak berani menatap lawan bicara

11. Lebih banyak menunduk

12. Bicara lambat dengan nada suara lemah

\subsubsection{Mekanisme Koping Harga Diri Rendah}

Mekanisme koping termasuk pertahanan koping jangka panjang pendek atau jangka panjang serta penggunaan mekanisme 
pertahanann ego untuk melindungi diri sendiri dalam menghadapi persepsi diri yang menyakitkan (Eko, 2014). Pertahanan tersebut mencakup berikut ini :

Jangka pendek :

1. Aktivitas yang memberikan pelarian semestara dari krisis identitas diri (misalnya, konser musik, bekerja keras, menonton tv secara obsesif) .

2. Aktivitas yang memberikan identitas pengganti semestara ( misalnya, ikut serta dalam klub sosial, agama, politik, kelompok, gerakan, atau geng).

3. Aktivitas yang sementara menguatkan atau meningkatkan perasaan diri yang tidak menentu ( misalnya, olahraga yang kompetitif, prestasi akademik, kontes untuk mendapatkan popularitas)

Menurut Pardede (2019), pertahanan jangka panjang mencakup berikut ini :

1. Penutupan identitas : adopsi identitas prematur yang diinginkan oleh orang terdekat tanpa memerhatikan keinginan,aspirasi,atau potensi diri individu

2. Identitas negatif : asumsi identitas yang tidak sesuai dengan nilai dan harapan yang diterima masyarakat. Mekanisme pertahanan ego termasuk penggunaan fantasi, disosiasi, isolasi, proyeksi, pengalihan (displacement, berbalik marah terhadap diri sendiri, dan amuk).

\subsubsection{Penatalaksanaan Keperawatan Harga Diri Rendah Kronis}

Terapi pada gangguan jiwa skizofrenia dewasa ini sudah dikembangkan sehingga penderita tidak mengalami diskriminasi bahkan metodenya lebih manusiawi dari pada masa sebelumnya (Pardede, Keliat, \& Yulia, 2020). Terapi yang dimaksud meliputi : 
1. Psikofarmaka

Berbagai jenis obat psikofarmaka yang beredar dipasaran yang hanya diperoleh dengan resep dokter, dapat dibagi dalam 2 golongan yaitu golongan generasi pertama (typical) dan golongan kedua (atypical). Obat yang termasuk golongan generasi pertama misalnya chlorpromazine HCL (psikotropik untuk menstabilkan senyawa otak), dan Haloperidol (mengobati kondisi gugup). Obat yang termasuk generasi kedua misalnya, Risperidone (untuk ansietas), Aripiprazole (untuk antipsikotik).

2. Psikoterapi

Terapi kerja baik sekali untuk mendorong penderita bergaul lagi dengan orang lain, penderita lain, perawat dan dokter, maksudnya supaya ia tidak mengasingkan diri lagi karena bila ia menarik diri ia dapat membentuk kebiasaan yang kurang baik. Dianjurkan untuk mengadakan permainan atau latihan bersama (Rokhimma \& Rahayu, 2020)

\subsection{Konsep Asuhan Keperawatan Harga Diri Rendah}

Gangguan konsep diri : Harga diri rendah adalah perasaan tidak berharga, tidak berarti dan rendah diri akibat evaluasi negatif terhadap diri sendiri dan kemampuan diri.Harga diri rendah dibagi menjadi harga diri rendah situasional dan harga diri rendah kronik. Harga diri rendah situasional yaitu munculnya persepsi negatif tentang makna diri sebagai respons terhadap situasi saat ini.Sedangkan, harga diri rendah kronik merupakan evaluasi diri atau perasaan negatif tentang diri sendiri atau kemampuan diri dalam waktu lama yang dapat mengganggu kesehatan (Safitri, 2020).

\subsubsection{Identitas}

Identitas pasien meliputi nama, umur, jenis kelamin Pendidikan agama, pekerjaan, suku/bangsa, alamat, nomer medik, ruang rawat, tanggal masuk rumah sakit, tanggal pengkajian, diagnose medis dan identitas penanggung jawab. 


\subsubsection{Alasan Masuk}

Tanyakan kepada pasien dan keluarga apa alasan pasien dibawa ke rumah sakit, Keluhan utama pasien dengan harga diri rendah kronis biasanya merenung atau menyendiri serta mengkritik atau menyalahkan diri sendiri.

\subsubsection{Faktor Presipitasi}

Masalah khusus tentang harga diri rendah kronis disebabkan oleh setiap situasi yang dihadapi individu dan ia tak mampu menyelesaikan masalah yang di hadapi . Situasi atas stressor ini dapat mempengaruhi terjadinya harga diri rendah kronis.

\subsubsection{Faktor Predisposisi}

a. Riwayat Kesehatan Dahulu

1) Adanya riwayat gangguan pada pasien atau keluarga.

2) Adanya gangguan fisik atau penyakit termasuk gangguan pertumbuhan dan perkembangan.

b. Riwayat Psikososial

1) Pada pasien harga diri rendah riwayat psikososial yang perlu diketahui adalah pernah atau tidak melakukan atau mengalami dan atau menyaksikan penganiayaan fisik, seksual, penolakan dari lingkungan, kekerasan dalam rumah tangga, aniaya, dan tindakan kriminal.

2) Merasakan pengalaman masa lalu lain yang tidak menyenangkan baik bio, psiko, sosio, kultural, maupun spiritual.

c. Riwayat Penyakit Keluarga Harga diri rendah kronis dapat disebabkan oleh keturunan. Oleh karena itu, pada riwayat penyakit keluarga harus dikaji apakah ada keluarga yang pernah mengalami gangguan jiwa. 


\subsubsection{Pemeriksaan Fisik}

Pada pemeriksaan fisik dilakukan pemeriksaan tanda-tanda vital (TTV), meliputi tekanan darah, nadi, suhu, pernafasan. Pemeriksaan keseluruhan tubuh yaitu pemeriksaan head to toe yang biasanya penampilan pasien yang kotor dan acak-acakan serta penampilannya tidak terawat.

\subsubsection{Psikososial}

A. Konsep diri

1) Gambaran diri Disukai ataupun tidak di sukai pasien mengatakan tidak ada keluan apapun.

2) Identitas diri Kaji kepuasan pasien terhadap jenis kelaminya, status sebelum dirawat di rumah sakit. Pasien merasa tidak berdaya dan rendah diri sehingga tidak mempunyai status yang di banggakan atau di harapkan di keluarga ataupun masyarakat.

3) Peran Biasanya pasien mengalami penurunan produktifitas dan merasa tidak mampu dalam melaksanakan tugas.

4) Ideal diri Tanyakan harapan tubuh, posisi status, peran. Harapan pasien terhadap lingkungan, dan harapan pasien terhadap penyakitnya.

5) Harga diri Pasien mengejek dan mengkritik dirinya sendiri, menurunkan martabat, menolak kemampuan yang dimiliki.

B. Genogram

Buatlah genogram minimal tiga generasi yang dapat menggambarkan hubungan pasien dan keluarga. Jelaskan pasien tinggal dengan siapa dan apa hubunganya, jelaskan masalah yang terkait dengan pola asuh keluarga terhadap pasien dan anggota keluarga lainya, pola komunikasi, pola pengambilan keputusan (Nyumirah, 2013). 
- Hubungan sosial

1) Pasien tidak mempunyai orang yang di anggap sebagai tempat mengadu dan meminta dukungan.

2) Pasien merasa berada di lingkungan yang mengancam.

3) Keluarga kurang memberikan penghargaan kepada pasien.

4) Pasien sulit berinteraksi.

- Spiritual

1) Falsafah hidup Pasien merasa perjalanan hidupnya penuh dengan ancaman, tujuan hidupnya biasanya jelas.

2) Konsep kebutuan dan praktek keagamaan Pasien mengakui adanya tuhan tapi tidak yakin terhadap tuhan, putus asa karena tuhan tidak memberikan sesuai apa yang dia inginkan dan tidak mau menjalankan kegiatan agama.

\subsubsection{Status Mental}

a. Penampilan Penampilan tidak rapi karena pasien kurang minat untuk perawatan diri. Kemunduran dalam tingkat kebersihan dan kerapian, bau badan karena tidak mandi merupakan salah satu tanda gangguan jiwa dengan harga diri rendah kronis.

b. Pembicaraan Pasien dengan frekuensi lambat, tertatah, volume suara rendah, sedikit berbicara inkoheren dan bloking

c. Aktivitas Motorik Tegang, lambat, gelisah, dan terjadi penurunan aktivitas interaksin

d. Alam Perasaan Pasien biasanya merasakan tidak mampu dan pandangan hidupnya selalu pesimis

e. Afek Terkadang afek pasien tampak tumpul, emosi pasien berubahubah, kesepian, apatis, depresi atau sedih, dan cemas.

f. Interaksi selama wawancara

1) Tidak kooperatif, atau mudah tersinggung.

2) Kontak mata kurang: tidak mau menatap lawan bicara.

3) Defensif: selalu mempertahankan pendapat dan kebenaran dirinya. 
4) Curiga: menunjukkan tidak percaya pada orang lain.

g. Persepsi Pasien mengalami halusinasi dengar/lihat yang mengancam atau memberi perintah

h. Proses pikir Data yang diperoleh dari observasi pada saat wawancara:

1) Arus Pikir:

a) Koheren: pembicaraan dapat dipahami dengan baik.

b) Inkoheren: kalimat tidak berbentuk, kata-kata sulit dipahami.

c) Tangensial: pembicaraan yang berbelit-belit tapi tidak sampai pada tujuan.

d) Flight of ideas: pembicaraan yang melompat dari satu topik ke topik lainnya masih ada hubungan yan tidak logis dan tidak sampai pada tujuan.

e) Bloking: pembicaraan terhenti tiba-tiba kemudian dilanjutkan kembali.

f) Neologisme: membentuk kata-kata baru yang tidak di pahami oleh umum.

g) Sosiasi bunyi: mengucapkan kata-kata yang mempunyai persamaan bunyi.

2) Isi Pikir: Merasa bersalah dan khawatir, menghukum atau menolak diri sendiri, mengejek dan mengkritik diri sendiri (Yusuf, 2015).

\subsubsection{Tingkat kesadaran}

a. Biasanya pasien tampak bingung dan kacau, stupor adalah gangguan motorik seperti kelakuan, gerakan berulang-ulang, anggota tubuh pasien dalam sikap canggung yang dipertahankan dalam waktu lama tetapi pasein menyadari semua yang terjadi dilingkungan, sedasi yaitu pasien mengatakan bahwa ia merasa melayang-layang antara sadar atau tidak sadar. 
b. Tingkat konsentrasi berhitung

1) Peratikan pasien mudah berganti dari satu obyek ke obyek lain atau tidak.

2) Tidak mampu berkonsentrasi.

3) Tidak mampu berhitung.

c. Kemampuan penilaian

1) Ringan: dapat mengambil suatu keputusan yang sederhana dengan dibantu.

2) Bermakna : tidak mampu mengambil suatu keputusan walaupun sudah dibantu.

d. Daya titik diri Pasien tidak menyadari bahwa dia mengalami gangguan jiwa. 


\section{BAB 3 \\ TINJAUAN KASUS}

Ruang rawat $\quad$ : Lingk. XVI Lorong Jaya, Mabar Kec. Medan Deli.

Tanggal MRS : 2 Maret 2021

\subsection{Identitas Klien}

Inisial

: An. A

Jenis kelamin

: Laki-Laki

Umur

: 13 Tahun

Agama

: Kristen

Status

: Anak ke 3

Tanggal pengkajian

: 2 Maret 2021

RM No

Informent

:Status klien dan komunikasi dengan klien

\subsection{Alasan Masuk Rumah Sakit}

Alasan pasien masuk rumah sakit adalah pasien merasa dirinya tidak berguna dan sering sendiri sambil berfikir hal-hal yang negative pada dirinya. Ketika pertama kali masuk kerumah sakit pasien sempat marah-marah kepada orangtuanya. Pasien juga tidak mau pernah mandi, ketika pasien disuruh mandi pasien marah-marah.

\subsection{Faktor Predisposisi}

Pasien sebelumnya tidak pernah ada riwayat gangguan jiwa. Pertama kali pasien mengalami gangguan jiwa ketika pasien mengalami pristiwa hilangnya penglihatan pasien. Keluarga mengatakan pada saat pasien tidak bisa melihat dan membaca seperti anak lainnya pasien sempat marah dan menangis di kamar. Pasien juga mengatakan "aku tidak bisa apa-apa" pasien juga sempat menolak diajak berbicara dan berintraksi. Pasien juga sempat dibawa berobat kampung (dukun) tetapi tidak ada perubahan pada pasien tersebut, dan akhirnya keluarga memutuskan untuk membawa pasien ke rumah sakit jiwa. Ketika pasien dirawat di rumah sakit jiwa selama 3 hari pasien ingin meminta 
pulang karena dia tidak suka berada disana da orang tua pasien juga merasa gelisah jika berada jauh dengan anaknya dan dokter juga menyuruh keluarga membawa pulang pasien. Sepulang dari rumah sakit pasien hanya minum obat secara teratur selama 1 bulan saja, pasien mengalami gangguan jiwa \pm 3 tahun. Selama \pm 3 tahun pasien tidak pernah mengkonsumsi obat secara teratur lagi. Pasien sering melihat teman-temannya melakukan kegiatan yang bisa mereka lakukan dan tidak bisa dia lakukan. Terkadang pasien suka merenung dan termenung ketika sedang merasa sendiri. Keluarga pasien tidak ada yang pernah mengalami gangguan jiwa.

Masalah Keperawatan : Harga diri rendah.

\subsection{Fisik}

Klien tidak memiliki keluhan fisik, saat dilakukan pemeriksaan tanda-tanda vital, didapatkan hasil TD : 110/80 mmHg ; $\mathrm{N}: 80 \mathrm{x} / \mathrm{i} ; \mathrm{S}: 36,5^{\circ} \mathrm{C} ; \mathrm{P}: 22 \mathrm{x} / \mathrm{i}$. Klien memiliki tinggi badan $136 \mathrm{~cm}$ dan berat badan $42 \mathrm{Kg}$.

\subsection{Psikososial}

\section{a) Genogram}

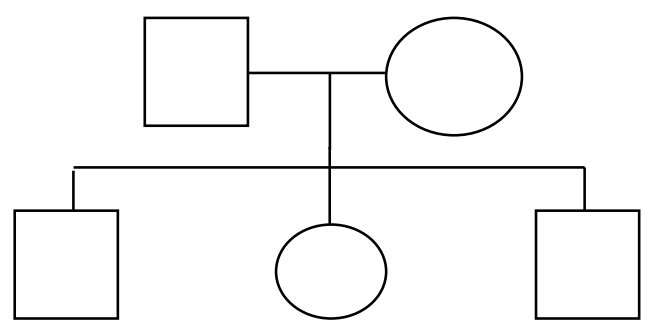

Px tinggal di Lingk. XVI Lorong Jaya, Mabar Kec. Medan Deli. Klien mempunyai ayah satu dan ibu satu, serta mempunyai kakak satu, abang satu, satu, klien adalah anak ke tiga dari tiga bersaudara, klien mengalami gangguan jiwa dan keluarga dalam keadaan sehat fisik dan psikologis serta tidak mengalami gangguan jiwa (sehat jiwa).

Keterangan:

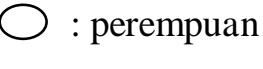

$\square$ : laki-laki 
$\square: T n . \mathrm{L}$

$\sqcap$ : garis keturunan

$\sqcup$ : garis perkawinan

:

$\mathrm{X}$ : meninggal

\section{b) Konsep Diri}

a. Gambaran diri : Klien menyukai seluruh tubuhnya dan tidak ada yang cacat

b. Identitas : Klien anak ke 3 dari 3 bersaudara

c. Peran : Klien berperan sebagai anak

d. Ideal diri : Klien ingin cepat sembuh

e. Harga diri : Klien merasa tidak berarti lagi dalam keluarganya

Masalah Keperawatan : Harga diri rendah

\section{c) Hubungan Sosial}

1. Orang yang berarti : orang yang berarti dalam kehidupan pasien adalah mamanya dikarenakan mamanya yang menjaga dan merawat pasien tersebut

2. Peran serta dalam kegiatan kelompok/masyarakat: Pasien tidak pernah mengikuti kegiatan kelompok lingkungan rumah

3. Hambatan dalam berbuhungan dengan orang Lain : klien tidak mudah akrab/ berhubungan dengan orang lain yang dia tidak kenal

\section{d) Spiritual}

1. Nilai dan Keyakinan : Klien beragama kristen dan yakin kepada Tuhan Yesus

2. Kegiatan Ibadah : Klien jarang ibadah Masalah keperawatan : Tidak Ada Masalah Keperawatan 


\section{e) Status Mental}

1) Penampilan

Klien tampak kurang rapi dalam berpakaian

2) Pembicaraan

Klien masih mampu menjawab pertanyaan perawat dengan lambat dan tidak jelas namun dapat dipahami

3) Aktivitas Motorik

Klien mengatakan bisa melakukan aktivitas sehari - hari.

4) Suasana perasaan

Klien sedih karena tinggal di rumah sendiri, Masalah keperawatan : Harga Diri Rendah

5) Afek

Afek wajah sesuai dengan topic pembicaraan

6) Interaksi selama wawancara

Klien kooperatif saat wawancara

7) Persepsi

Klien mengatakan bahwa ia tidak dapat memproses cepat setiap orang berbicara atau bertanya padanya

8) Proses Pikir

Klien mampu menjawab apa yang ditanya dengan baik.

9) Isi piker

Klien dapat mengontrol isi pikirnya,klien tidak mengalami gangguan isi pikir dan tidak ada waham. Klien tidak mengalami fobia, obsesi ataupun depersonalisasi.

10) Tingkat kesadaran

Klien tidak mengalami gangguan orientasi, klien mengenali waktu, orang dan tempat.

11) Memori

Klien mampu menceritakan kejadian di masa lalu dan yang pernah klein alami

12) Tingkat konsentrasi berhitung 
Klien sulit berkonsentrasi dalam perhitungan sederhana tanpa dan harus di bantu orang lain.

13) Kemampuan penilaian

Klien dapat membedakan hal yang baik dan yang buruk (mampu melakukan penilaian).

14) Daya tilik diri

Klien tidak mengingkari penyakit yang diderita, klien mengetahui bahwa dia sedang sakit

\subsection{Mekanisme Koping}

Klien mengalami mekanisme koping adaptif yaitu klien dapat berbicara cukup baik dengan orang lain.

\subsection{Masalah Psikososial dan Lingkungan}

Klien mengatakan sulit berteman dengan orang lain karena klien dan tidak sempat untuk melakukan kumpul-kumpul bersama masyarakat sekitar.

\subsection{Pengetahuan Kurang Tentang Gangguan Jiwa}

Klien tidak mengetahui tentang penyakit gangguan jiwa dan klien tidak tahu obat apa yang harus diminum untuk mengatasi gangguan jiwanya.

\subsection{Analisa Data}

\begin{tabular}{|c|c|c|}
\hline No & \multicolumn{1}{|c|}{ Analisa Data } & Masalah keperawatan \\
\hline 1 & DS : & Gangguan konsep diri : Harga \\
& • Keluarga mengatakan klien & Diri Rendah \\
& sering termenung sendiri & \\
& - Klien sering memperhatikan & \\
& temannya bermain dari jauh & \\
& - Klien sering menonton tv jika \\
& pagi hari, dan sebelum tidur \\
& malam klien sering berbicara & \\
& DO : \\
& - Klien tampan mamanya termenung & \\
\hline
\end{tabular}




\begin{tabular}{|c|c|c|}
\hline & $\begin{array}{l}\text { - Klien kurang jelas berbicara } \\
\text { dan terkadang tidak } \\
\text { nyambung saat ditanyak } \\
\text { - } \text { Klien juga terkadang ngobrol } \\
\text { sama mamanya }\end{array}$ & \\
\hline 2 & $\begin{array}{l}\text { DS : } \\
\text { - Klien sering menyendiri, } \\
\text { bicara sendiri, bingung, sulit } \\
\text { tidur, tidak mau makan, } \\
\text { jarang sekali bergaul } \\
\text { dengan lingkungan, karena } \\
\text { klien merasa malu dan juga } \\
\text { merasa dirinya dimusuhi } \\
\text { oleh adik kandungnya } \\
\text { hingga akhirnya klien } \\
\text { memukul adik kandungnya, } \\
\text { terkadang jan } \\
\text { klien juga marah-marah dan } \\
\text { berteriak jika dipaksa untuk } \\
\text { makan dan minum } \\
\text { DO : } \\
\text { klien sering terlihat } \\
\text { melamun tan } \\
\text { klien tampak bingung dan } \\
\text { bicara sendiri, klien kurang } \\
\text { kooperatif, menundukan } \\
\text { kepala saat wawancara, } \\
\text { dan pendiam dan suka } \\
\text { menyendiri } \\
\text { Klien tampak menghindari } \\
\text { Isolasi Sosial interaksi, } \\
\text { terlihat sedih, pendangan } \\
\text { menunduk kebawah dan } \\
\text { klien tidak mempunyai } \\
\text { teman. }\end{array}$ & Isolasi Sosial : Menarik Diri \\
\hline
\end{tabular}

\subsection{Masalah Keperawatan}

1. Isolasi Sosial : Menarik Diri

2. Harga diri rendah (HDR)

3. Ketidakefektifan Mekanisme Koping 


\subsection{Pohon Masalah}

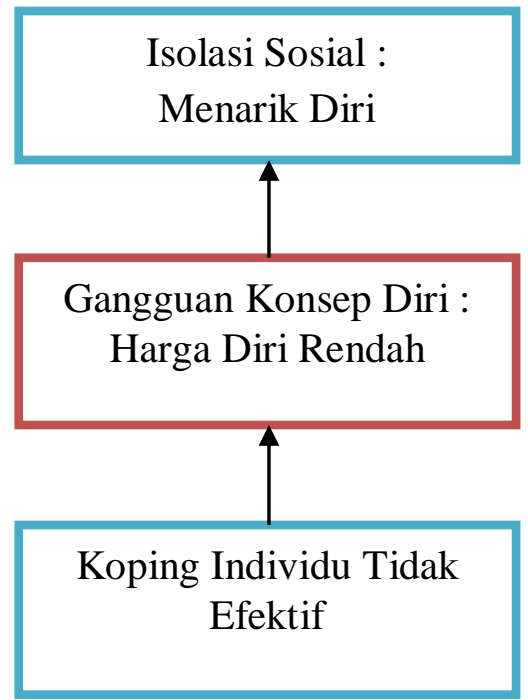

\subsection{Prioritas Diagnosa Keperawatan}

1. Gangguan Konsep Diri : Harga Diri Rendah

2. Isolasi Sosial : Menarik Diri

\subsection{Intervensi Keperawatan}

\begin{tabular}{|c|c|c|}
\hline No & Diagnosa Keperawatan & Intervensi \\
\hline 1 & Harga Diri Rendah & $\begin{array}{l}\text { Sp } 1 \text { : } \\
\text { Mengindentifikasi kemampuan dan } \\
\text { aspek positif yang dimiliki pasien. } \\
\text { Sp } 2 \text { : } \\
\text { a. Menilai kemampuan yang dapat di } \\
\text { gunakan. } \\
\text { b. Menetapkan/ memilih kegiatan } \\
\quad \text { sesuai kemampuan. } \\
\text { c. Melatih kegiatan sesuai } \\
\quad \text { kemampuan yang dipilih 1. } \\
\text { Sp } 3 \text { : } \\
\text { Melatih kegiatan sesuai kemampuan } \\
\text { yang dipilih } 2 \text {. } \\
\text { Sp } 4 \text { : } \\
\text { Melatih kegiatan sesuai kemampuan } \\
\text { yang dipilih 3. }\end{array}$ \\
\hline
\end{tabular}




\begin{tabular}{|c|c|c|}
\hline 2 & $\begin{array}{l}\text { Isolasi Sosial : Menarik } \\
\text { Diri }\end{array}$ & $\begin{array}{l}\text { Sp 1: } \\
\text { Menjelaskan keuntungan dan kerugian } \\
\text { mempunyai teman. } \\
\text { Sp 2: } \\
\text { Melatih klien berkenalan dengan } 2 \\
\text { orang atau lebih. } \\
\text { Sp 3: } \\
\text { Melatih bercakap-cakap sambil } \\
\text { melakukan kegiatan harian. } \\
\text { Sp } 4 \text { : } \\
\text { Melatih berbicara sosial meminta } \\
\text { seuatu, belanja dan sebagainya. }\end{array}$ \\
\hline
\end{tabular}




\subsection{Implementasi dan Evaluasi}

\begin{tabular}{|c|c|c|}
\hline Hari / Tgl & Implementasi & Evaluasi \\
\hline $\begin{array}{l}\text { Kamis, } \\
04 \text { Maret } 2021\end{array}$ & $\begin{array}{l}\text { Data } \\
\text { - Klien merasa tidak berguna karena tidak dapat membantu } \\
\text { keluarga. } \\
\text { - Klien merasa minder karena penyakit yang di alaminya } \\
\text { - Klien merasa minder karena tidak bisa lancar membaca } \\
\quad \text { dan menulis dengan baik } \\
\text { - Klien terkadang berasa sedih jika sendirian dirumah } \\
\text { - Klien merasa malu dengan teman-teman } \\
\text { - Klien tampak murung } \\
\text { Diagnosa Keperawatan } \\
\text { Gangguan Konsep Diri : Harga Diri Rendah } \\
\text { Tindakan Keperawatan } \\
\text { Sp 1: } \\
\text { Mengidentifikasi kemampuan dan aspek positif yang dimiliki } \\
\text { pasien } \\
\text { RTL: }\end{array}$ & $\begin{array}{l}\text { S : } \\
\text { Senang } \\
\text { O : } \\
\text { Klien mampu Mengidentifikasi aspek positif yang } \\
\text { dimiliki pasien yaitu bernyanyi dan berdoa. } \\
\text { A : } \\
\text { Harga Diri Rendah (+) } \\
\text { P : } \\
\text { Latihan memulai segala aktivitas nya dengan Doa. }\end{array}$ \\
\hline
\end{tabular}




\begin{tabular}{|c|c|c|}
\hline & $\begin{array}{l}\text { SP } 2 \\
\text { a. Menilai kemampuan yang dapat digunakan } \\
\text { b. Menetapkan atau memilih kegiatan sesuai kemampuan } \\
\text { c. Melatih kegiatan sesuai kemampuan yang dipilih } 1\end{array}$ & \\
\hline $\begin{array}{l}\text { Pukul 17.00- } \\
\text { selesai }\end{array}$ & $\begin{array}{l}\text { Data } \\
\text { - Klien merasa tidak berguna karena tidak dapat membantu } \\
\text { keluarga. } \\
\text { - Klien merasa minder karena penyakit yang di alaminya } \\
\text { - Klien merasa minder karena tidak bisa lancar membaca } \\
\text { dan menulis dengan baik } \\
\text { - Klien terkadang berasa sedih jika sendirian dirumah } \\
\text { - Klien merasa malu dengan teman-teman } \\
\text { - Klien tampak murung } \\
\text { Diagnosa Keperawatan } \\
\text { Gangguan Konsep Diri : Harga Diri Rendah } \\
\text { Tindakan Keperawatan } \\
\text { Sp } 2 \text { Harga Diri Rendah : } \\
\text { a. Menilai kemampuan yang dapat digunakan }\end{array}$ & $\begin{array}{l}\text { S: } \\
\text { Senang dan Antusias } \\
\text { O : } \\
\text { Klien mampu memilih dan melatih kegiatan sesuai } \\
\text { kemampuan yaitu membantu ibu menyelesaikan } \\
\text { perkerjaan rumah dan bernyanyi } \\
\text { A : } \\
\text { Harga Diri Rendah (+) } \\
\text { P : } \\
\text { Latihan membersikan rumah dan bernyanyi }\end{array}$ \\
\hline
\end{tabular}




\begin{tabular}{|c|c|c|}
\hline & $\begin{array}{l}\text { b. Menetapkan atau memilih kegiatan sesuai } \\
\text { kemampuan } \\
\text { c. Melatih kegiatan sesuai kemampuan yang dipilih } 1 \\
\text { RTL : } \\
\text { Sp } 3 \text { : Melatih kegiatan sesuai kemampuan yang dipilih } 2\end{array}$ & \\
\hline $\begin{array}{l}\text { Selasa, } \\
16 \text { Maret } 2021\end{array}$ & $\begin{array}{l}\text { Data } \\
\text { - Klien merasa tidak berguna karena tidak dapat membantu } \\
\text { keluarga. } \\
\text { - Klien merasa minder karena tidak bisa lancar membaca } \\
\text { dan menulis dengan baik } \\
\text { - Klien terkadang berasa sedih jika sendirian dirumah } \\
\text { - Klien merasa malu dengan teman-teman } \\
\text { Diagnosa Keperawatan } \\
\text { Gangguan Konsep Diri : Harga Diri Rendah } \\
\text { Tindakan Keperawatan } \\
\text { Sp 3: Melatih kegiatan sesuai kemampuan yang dipilih } 2 \\
\text { RTL: } \\
\text { Sp } 4 \text { : Melatih kegiatan sesuai kemampuan yang dipilih } 3\end{array}$ & $\begin{array}{l}\text { S : } \\
\text { Senang dan Antusias } \\
\text { O : } \\
\text { Klien mampu melatih kegiatan sesuai kemampuan } \\
\text { yaitu menyuci piring dan menyapu rumah } \\
\text { A : } \\
\text { Harga Diri Rendah (+) } \\
\text { P : } \\
\text { - Berdoa, Mengikuti ibadah } \\
\text { - Membantu menyapu rumah } \\
\text { - Menyuci piring }\end{array}$ \\
\hline
\end{tabular}




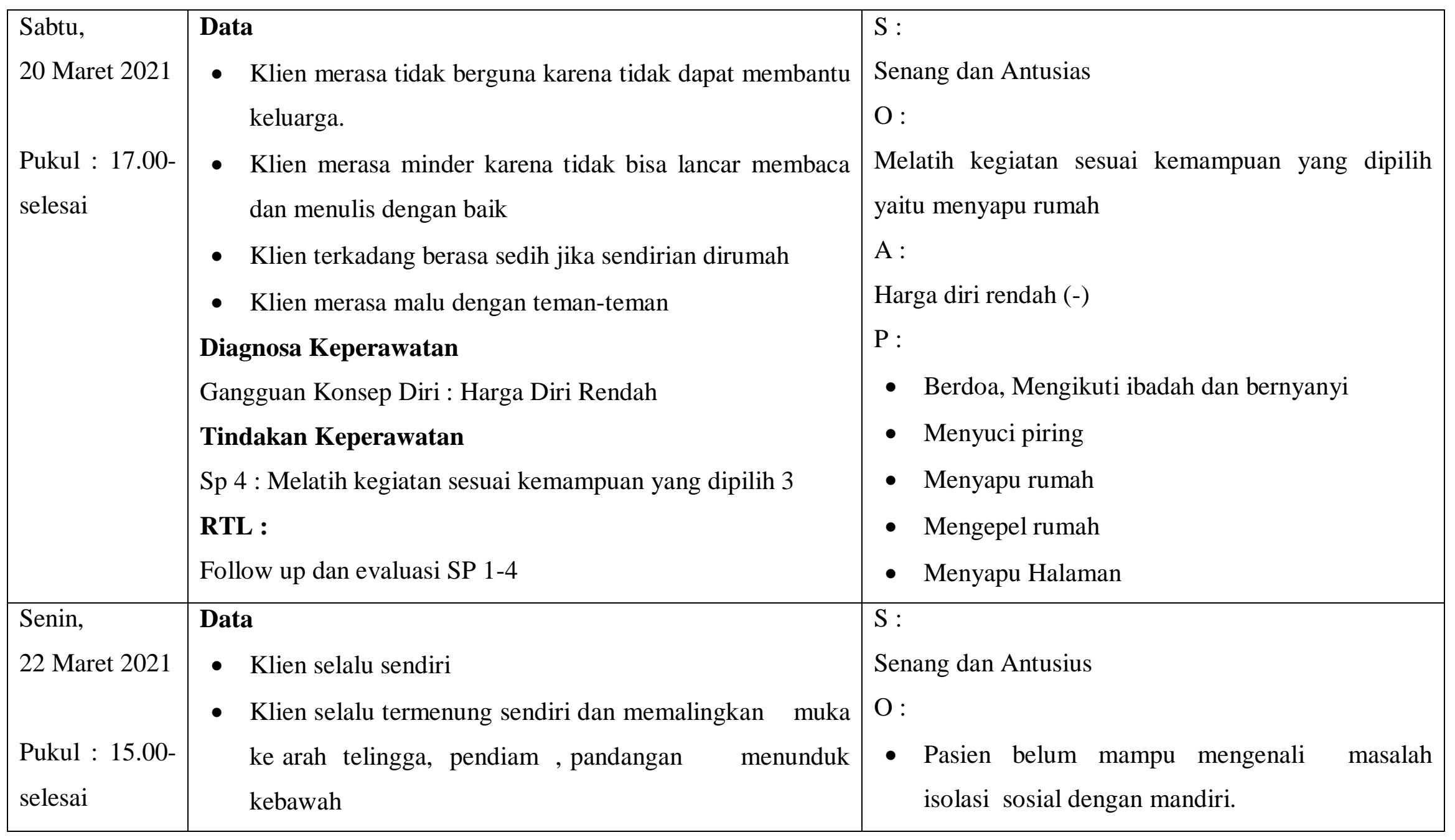




\begin{tabular}{|c|c|c|}
\hline & $\begin{array}{l}\text { - Klien tidak punya teman } \\
\text { Diagnosa Keperawatan } \\
\text { Isolasi Sosial } \\
\text { Tindakan Keperawatan } \\
\text { Sp1 : Menjelaskan keuntungan dan kerugian mempunyai } \\
\text { teman } \\
\text { RTL: } \\
\text { Sp } 2 \text { : Melatih klien berkenalan dengan } 2 \text { orang atau lebih }\end{array}$ & $\begin{array}{l}\text { - } \text { Mengidentifikasi isolasi sosialnya ; tanda dan } \\
\text { gejala, penyebab dan akibat dari isolasi sosial } \\
\text { - Pasien belum mampu menjelaskan } \\
\text { keuntungan memiliki teman dan kerugian } \\
\text { memiliki teman dengan mandiri. } \\
\text { A : } \\
\text { Isolasi Sosial (+) } \\
\text { P : } \\
\text { - Latihan mengidentifikasi isolasi sosialnya ; } \\
\text { tanda dan gejala, penyebab dan akibat dari } \\
\text { isolasi sosial } \\
\text { - Menjelaskan keuntungan memiliki teman dan } \\
\text { kerugian memiliki teman. }\end{array}$ \\
\hline $\begin{array}{l}\text { Pukul : 15.00- } \\
\text { selesai }\end{array}$ & $\begin{array}{l}\text { Data } \\
\text { - Klien selalu sendiri } \\
\text { - Klien selalu termenung sendiri dan memalingkan muka } \\
\text { ke arah telingga, pendiam, pandangan menunduk } \\
\text { kebawah }\end{array}$ & $\begin{array}{l}\text { S : } \\
\text { Senang dan Antusias } \\
\text { O : } \\
\text { - Klien mampu menjelaskan cara } \\
\text { dengan bantuan. }\end{array}$ \\
\hline
\end{tabular}




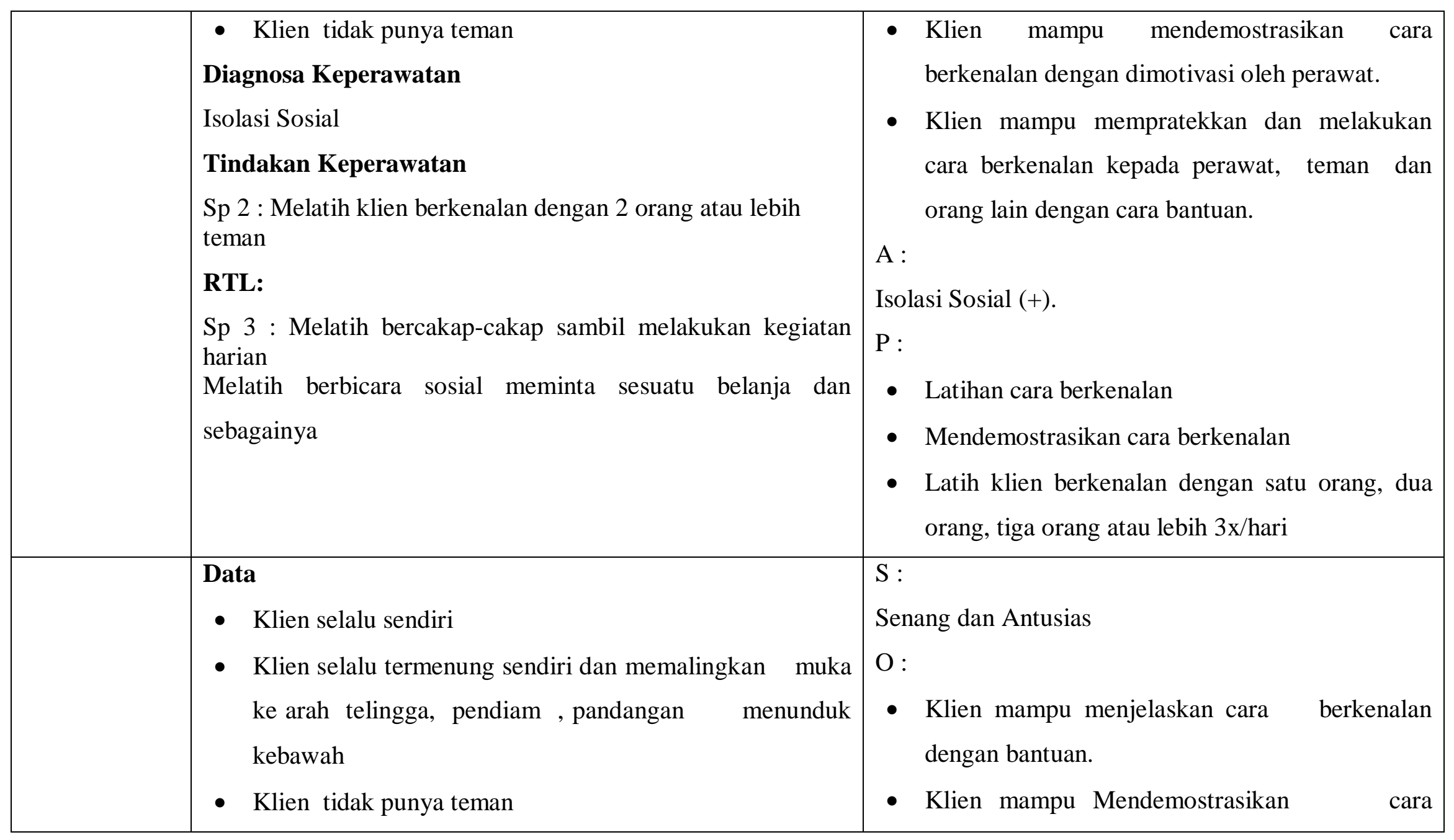




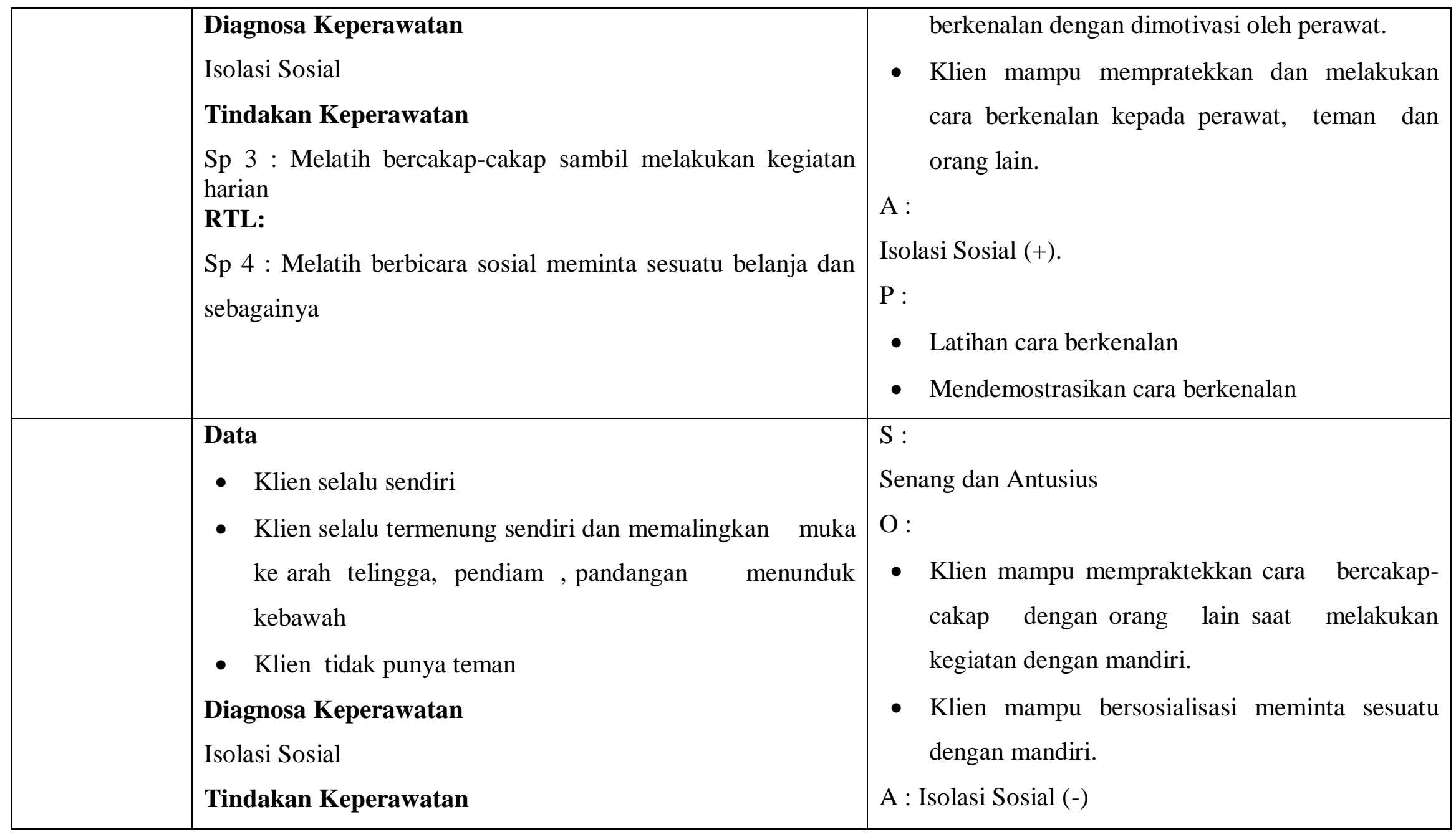




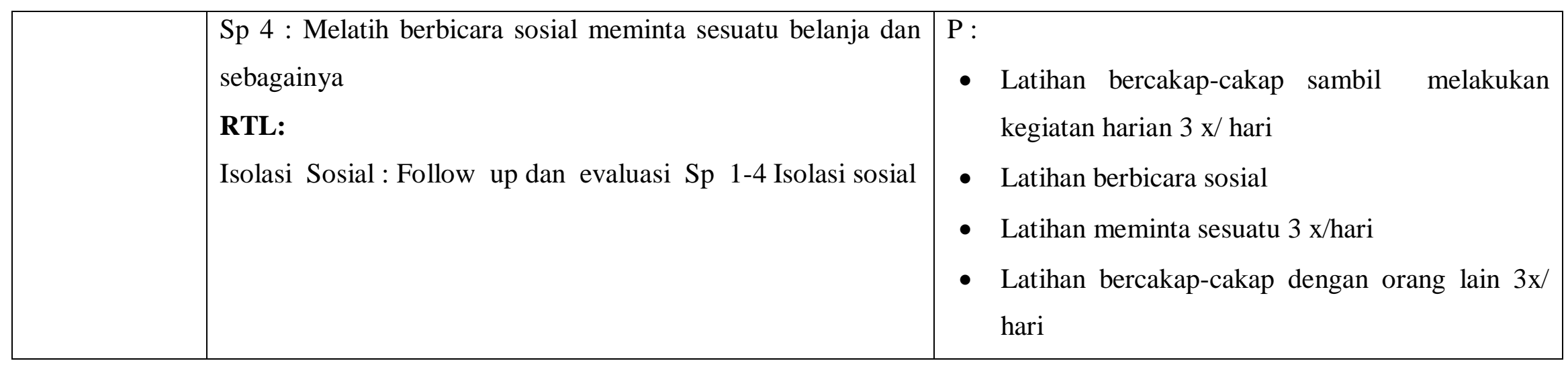




\section{BAB 4 \\ PEMBAHASAN}

Setelah penulis melaksanakan asuhan keperawatan kepada An. A dengan gangguan konsep diri : harga diri rendah Lingk. XVI Lorong Jaya, Mabar Kec. Medan Deli, maka penulis pada BAB ini akan membahas kesenjangan antara teoritis dengan tinjauan kasus. Pembahasan dimulai melalui tahapan proses keperawatan yaitu pengkajian, diagnosa keparawatan, perencanaan, pelaksanaan dan evaluasi.

\subsection{Pengkajian}

Pada pembahasan ini diuraikan tentang hasil pelaksanaan tindakan keperawatan dengan pemberian terapi pada klien harga diri rendah. Pembahasan menyangkut analisis hasil penerapan terapi terhadap masalah keperawatan harga diri rendah. Tindakan keperawatan didasarkan pada pengkajian dan diagnosis keperawatan yang terdiri dari tindakan yang dijabarkan sebagai berikut :

Tahap pengkajian pada klien harga diri rendah dilakukan interaksi perawatklien melalui komunikasi terapeutik untuk mengumpulkan data dan informasi tentang status kesehatan klien. Pada proses pengkajian, data penting yang perlu didapatkan adalah data, keluhan, kemampuan dan situasi yang menyebabkan harga diri rendah (Masturah, 2017).

Selama pengkajian dilakukan pengumpulan data dari beberapa sumber, yaitu dari pasien dan keluarga pasien. Maka penulis melakukan pendekatan kepada pasien dan keluarga pasien melalui komunikasi terapeutik yang lebih terbuka membantu pasien untuk memecahkan perasaannya dan juga melakukan observasi kepada pasien. Adapun upaya tersebut yaitu:

1. Melakukan pendekatan dan membina

Melakukan hubungan saling percaya diri pada klien agar klien lebih terbuka dan lebih percaya dengan menggunakan perasaan. 
2. Mengadakan pengkajian klien dengan wawancara

Dalam pengkajian ini, penulis menemukan ditemukan. Pada kasus An. A susah melakukan pendekatan atau istraksi kepada orang lain, merasa malu dan merasa tidak mampu atau tidak memiliki kemampuan di diri sendiri. Gejala gejala yang dapat dinilai dari penampilan klien saat berinterkasi dengan peneliti maupun dengan keluarga. klien terlihat lebih banyak diam dan tidak mau memulai pembicaraan. Klien tidak mau bergaul dengan lingkungan sekitar. Klien lebih banyak berdiam diri di rumah. Klien merasa tidak memiliki kemampuan dan mengalami penurunan produktifitas (Astarani dan Minarso 2017). Akan tetapi terdapat faktor predisposisi maupun presipitasi yang menyebabkan kekambuhan penyakit yang dialami oleh An. A.

Tindakan yang dilakukan pada An. A adalah strategi pertemuan pertama sampai pertemuan empat. Strategi pertemuan pertama meliputi mengidentifikasi kemampuan dan aspek positif yang dimiliki pasien. Strategi pertemuan kedua yang dilakukan pada An. A meliputi menilai, menetapkan dan melatih kegiatan sesuai kemampuan yang dipilih 1 . Strategi pertemuan yang ketiga adalah melatih kegiatan sesuai kemampuan yang dipilih 2. Strategi pertemuan keempat adalah melatih kegiatan sesuai kemampuan yang dipilih 3 .

\subsection{Diagnosa Keperawatan}

Diagnosa keperawatan merupakan suatu penilaian klinis mengenai respons klien terhadap masalah kesehatan atau proses kehidupan yang dialaminya baik yang berlangsung actual maupun potensial. Diagnosis keperawatan bertujuan untuk mengidentifikasi respons klien individu, keluarga dan komunitas terhadap situasi yang berkaitan dengan kesehatan (Fadhillah, 2017). Diagnosa yang muncul pada kasus An. A yang meliputi: harga diri rendah. Dari hal tersebut di atas dapat dilihat terjadi kesamaan antara teori dan kasus. Dimana semua diagnosa pada teori muncul pada kasus An. A. 


\subsection{Implementasi}

Implementasi atau disebut tindakan keperawatan merupakan rangkaian perilaku atau aktivitas yang dikerjakan oleh perawat untuk mengimplementasikan intervensi keperawatan. Tindakan-tindakan pada intervensi keperawatan terdiri atas observasi, terapeutik, edukasi dan kolaborasi (Fadhillah, 2018). Pada tahap implementasi, penulis hanya mengatasi 1 masalah keperawatan yakni: diagnosa keperawatan harga diri rendah. Pada diagnosa keperawatan gangguan konsep diri : harga diri rendah dilakukan strategi pertemuan yaitu mengidentifikasi kemampuan dan aspek positif yang dimiliki pasien.. Kemudian strategi pertemuan yang dilakukan yaitu meliputi menilai, menetapkan dan melatih kegiatan sesuai kemampuan yang dipilih 1. Strategi pertemuan selanjutnya yaitu melatih kegiatan sesuai kemampuan yang dipilih 2. Dan strategi pertemuan terakhir melatih kegiatan sesuai kemampuan yang dipilih 3 .

\subsection{Evaluasi}

Setelah tindakan keperawatan, segera lakukan evaluasi. Evaluasi terhadap masalah keperawatan harga diri rendah meliputi kemampuan pasien harga diri rendah dan keluarganya dan kemampuan perawat dalam merawat pasien harga diri rendah (Tobing, Keliat \& Wardhani, 2014). Pada tinajauan teoritis evaluasi yang diharapkan adalah: Pasien mempercayai perawat sebagai terapi, pasien menyadari bahwa pasien memiliki kemampuan dan aspek yang dimiliki. Klien mampu mengindentifikasi kemampuan yang dimiliki , Klien mampu menilai, menetapkan dan melatih kegiatan sesuai kemampuan yang dipilih :

1. Strategi pertemuan selanjutnya yaitu Strategi pertemuan selanjutnya yaitu melatih kegiatan sesuai kemampuan yang dipilih .

2. Klien mampu melaksanakan jadwal yang telah dibuat bersama, Klien mampu melatih kegiatan sesuai kemampuan yang dipilih.

3. Selain itu, dapat dilihat dari setiap evalusi yang dilakukan pada asuhan keperawatan, dimana terjadi penurunan gejala yang dialami oleh An. A dari hari kehari selama proses interaksi. 


\section{BAB 5 \\ PENUTUP}

\subsection{Kesimpulan}

Berdasarkan uraian pada pembahasan di atas, maka penulis dapat menyimpulkan bahwa :

3. Pengkajian dilakukan secara langsung pada klien dan juga dengan menjadikan status klien sebagai sumber informasi yang dapat mendukung data-data pengkajian. Selama proses pengkajian, perawat mengunakan komunikasi terapeutik serta membina hubungan saling percaya antara perawat-klien. Pada kasus An. A diperoleh bahwa klien mengalami harga diri rendah seperti merasa sulit berkenalan dengan orang lain, merasa malu dan menganggap dirinya tidak memiliki kemampuan. Faktor predisposisi An. A yaitu tidak mengalami gangguan jiwa sebelumnya.

4. Diagnosa keperawatan yang muncul pada kasus An. A harga diri rendah, ketidakefektifan mekanisme koping dan terjadi isolasi diri : menarik diri. Tetapi pada pelaksanaannya, penulis fokus pada masalah utama yaitu harga diri rendah.

5. Perencanaan dan implementasi keperawatan disesuaikan dengan strategi pertemuan pada pasien harga diri rendah.

6. Evaluasi diperoleh bahwa terjadi peningkatan kemampuan klien dalam mengindentifikasi harga diri rendah yang dialami serta dampak pada gejala harga diri rendah yang dialami.

\subsection{Saran}

1. Bagi Perawat

Diharapkan dapat menerapkan komunikasi terapeutik dalam pelaksanaan strategi pertemuan 1-4 pada klien dengan harga diri rendah sehingga dapat mempercepat proses pemulihan klien. 
2. Bagi Institusi Pendidikan

Dapat meningkatkan bimbingan praktek lapangan kepada mahasiswa profesi ners sehingga mahasiswa semakin mampu dalam melakukan asuhan keperawatan pada pasien-pasien yang mengalami harga diri rendah.

3. Bagi Pasien Laporan ini diharapkan dapat menjadi acuan dan referensi dalam memberikan asuhan keperawatan pada klien dengan harga diri rendah. 


\section{DAFTAR PUSTAKA}

Astarani, K., \& Minarso, S. (2017). Gambaran Harga Diri Penderita Kusta Di Rumah Sakit Khusus Kusta Kota Kendiri. JURNAL STIKES RS Baptis Kediri, 10 (1). https://jurnal.stikesbaptis.ac.id/index.php/STIKES/article/view/231

Dermawan, D. (2013). Keperawatan Jiwa; Konsep Kerangka Kerja Asuhan Keperawatan Jiwa.

http://repo.unikadelasalle.ac.id/index.php?p=show_detail\&id=8253\&ke ywords

Eko, Prabowo. (2014). Konsep dan Aplikasi Asuhan Keperawatan Jiwa. Penerbit : Buku Kedokteran. Jakarta : EGC.

http://repo.unikadelasalle.ac.id/index.php?p=show_detail\&id=8012\&ke ywords $=$

Elvidiana, H., \& Fitriani, D. R. (2019). Analisis Praktik Klinik Keperawatan pada Ibu R dengan Harga Diri Rendah dengan Intervensi Inovasi Logoterapi Terhadap Gangguan Harga Diri Rendah di Ruang Punai RSJD Atma Husada Mahakam

Samarinda. https://dspace.umkt.ac.id//handle/463.2017/905

Fadhillah H. 2017. Standar Diagnosis Keperawatan Indonesia. Jakarta Selatan: DPP, PPNI

Fadhillah H. 2018. Standar Intervensi Keperawatan Indonesia. Jakarta Selatan: DPP, PPNI

Fatah, A. A. (2018). Asuhan Keperawatan Pada Pasien dengan Harga Diri Rendah Kronis di Rumah Sakit Jiwa Prof. HB Saanin Padang Tahun 2018. http://pustaka.poltekkespdg.ac.id/index.php?p=show_detail\&id=5154\& keywords $=$

Hidayati, N. W. (2016). Hubungan harga diri dan konformitas teman sebaya dengan kenakalan remaja. Jurnal Penelitian Pendidikan Indonesia, 1(2).

http://i-rpp.com/index.php/jpp/article/view/371/371371371

Tobing, D. L., Keliat, B. A., \& Wardhani, I. Y. (2014). Pengaruh Progressive Muscle Relaxationdan Logoterapi terhadap Kecemasan, Depresi, dan Kemampuan Relaksasi. Jurnal Keperawatan Padjadjaran, 2(2). https://doi.org/10.24198/jkp.v2i2.69

Kemenkes RI. (2019). Riset Kesehatan Dasar, RISKESDAS. Jakarta: Kemenkes RI. https://databoks.katadata.co.id/datapublish/2019/10/08/persebaranprevalensi-skizofreniapsikosis-di-indonesia\# 
Masturah, A. N. (2017). Gambaran konsep diri mahasiswa ditinjau dari perspektif budaya. Indigenous: Jurnal Ilmiah Psikologi, 2(2). https://doi.org/10.23917/indigenous.v2i2.4934

Muhith, A. (2015). Pendidikan keperawatan jiwa: Teori dan aplikasi. Penerbit Andi.https://books.google.co.id/books?id=Yp2ACwAAQBAJ\&printsec $=$ copyright $\&$ hl=id \&source=gbs_pub_info_r

Nyumirah, S. (2013). Peningkatan kemampuan interaksi sosial (kognitif, afektif dan perilaku) melalui penerapan terapi perilaku kognitif di rsj dr amino 43 gondohutomo semarang. Jurnal keperawatan jiwa, 1(2). https://doi.org/10.26714/jkj.1.2.2013.\%25p

Pardede, J. A., \& Laia, B. (2020). Decreasing Symptoms of Risk of Violent Behavior in Schizophrenia Patients Through Group Activity Therapy. Jurnal Ilmu Keperawatan Jiwa, 3 (3), 291-300. http://journal.ppnijateng.org/index.php/jikj/article/view/621/338

Pardede, J. A. (2019). The Effects Acceptance and Aommitment Therapy and Health Education Adherence to Symptoms, Ability to Accept and Commit to Treatment and Compliance in Hallucinations Clients Mental Hospital of Medan, North Sumatra. J Psychol Psychiatry Stud, 1, 30-35

Pardede, J. A., \& Hasibuan, E. K. (2019). Dukungan Caregiver Dengan Frekuensi Kekambuhan Pasien Skizofrenia. Idea Nursing Journal, 10(2). http://erepository.unsyiah.ac.id/INJ/article/view/17161

Pardede, J. A, Keliat, B. A, \& Yulia, I. (2015). Kepatuhan dan Komitmen Klien Skizofrenia Meningkat Setelah Diberikan Acceptanse And Commitment Theray dan Pendidikan Kesehatan Kepatuhan Minum Obat. Jurnal Keperawatan Indonesia, 18 (3), 157-166 http://jki.ui.ac.id/index.php/jki/article/view/419

Pardede, J. A, Keliat, B. A, \& Yuli, I. (2020). The Symptoms of Low Self-Esteem Decline after Being Given Acceptance and Commitment Therapy. Advanced Practices in Nursing, 5 (2), 2573-0347

Pitayanti, A., \& Hartono, A. (2020). Sosialisasi Penyakit Skizofrenia Dalam Rangka Mengurangi Stigma Negatif Warga di Desa Tambakmas Kebonsari-Madiun. Journal of Community Engagement in Health,3(2), 300-303. https://jceh.org/index.php/JCEH/article/view/83/78

Purwasih, R., \& Susilowati, Y. (2016). Penatalaksanaan Pasien Gangguan Jiwa Dengan Gangguan Konsep Diri: Harga Diri Rendah Di Ruang Gathotkoco Rsjd Dr. Amino Gondohutomo Semarang. Jurnal Profesi Keperawatan (JPK), 3 (2). 
http://jurnal.akperkridahusada.ac.id/index.php/jpk/article/view/26

Rahayu, S., Mustikasari, M., \& Daulima, N. H. (2019). Perubahan Tanda Gejala dan Kemampuan Pasien Harga Diri Rendah Kronis Setelah Latihan Terapi Kognitif dan Psikoedukasi Keluarga. JOURNAL EDUCATIONAL OF NURSING (JEN), 2(1), 39-51. https://doi.org/10.37430/jen.v2i1.10

Rokhimmah, Y., \& Rahayu, D. A. (2020). Penurunan Harga Diri Rendah dengan menggunakan Penerapan Terapi Okupasi (Berkebun). Ners Muda, 1(1), 18. https://doi.org/10.26714/nm.v1i1.5493

Safitri, A. (2020). Studi Literatur: Asuhan Keperawatan Keluarga Penderita Skizofrenia Dengan Gangguan Konsep Diri: Harga Diri Rendah Kronis (Doctoral dissertation, Universitas Muhammadiyah Ponorogo). http://eprints.umpo.ac.id/6155/

Sitanggang, R., Pardede, J. A., Damanik, R. K., \& Simanullang, R. H. (2021). The Effect Of Cognitive Therapy On Changes In Self-Esteem On Schizophrenia Patients. European Journal of Molecular \& Clinical Medicine, 7(11), 2696-2701. https://ejmcm.com/article 6267.html

Suhron, Muhammad. 2017. Asuhan Keperawatan Jiwa Konsep Self Esteem. Jakarta: Mitra Wacana Media. https://doi.org/10.23917/indigenous.v2i2.4934

Wakhid, A., Hamid, A. Y. S., \& CD, N. H. (2013). Penerapan Terapi Latihan Ketrampilan Sosial Pada Klien Isolasi Sosial Dan Harga Diri Rendah Dengan Pendekatan Model Hubungan Interpersonal Peplau Di Rs Dr Marzoeki Mahdi Bogor. Jurnal Keperawatan Jiwa, 1 (1). http://103.97.100.145/index.php/JKJ/article/view/911

Wandono, W. A., \& Arum Pratiwi, S. (2017). Upaya peningkatan harga diri rendah pada pasien depresi (Doctoral dissertation, Universitas Muhammadiyah Surakarta). http://eprints.ums.ac.id/id/eprint/52383

Yusuf, A dkk. (2015). Buku Ajar Keperawatan Kesehatan Jiwa. Jakarta Salemba Medika. http://eprints.umpo.ac.id/6107/ 